Article

\title{
New Approach to Sustainability in Rural Areas Comprising Agriculture Practices-Analysis of Demonstration Farms in the Czech Republic
}

\author{
Milada Št astná *(D), Veronika Peřinková, Pavla Pokorná and Antonín Vaishar ${ }^{\mathbb{D}}$ \\ Department of Applied and Landscape Ecology, Mendel University in Brno, Zemědělská 1, 61300 Brno, \\ Czech Republic; veronika.perinkova@mendelu.cz (V.P.); pavla.pokorna@mendelu.cz (P.P.); \\ antonin.vaishar@mendelu.cz (A.V.) \\ * Correspondence: stastna@mendelu.cz; Tel.: +420-606-580-412
}

Received: 6 April 2019; Accepted: 18 May 2019; Published: 22 May 2019

check for updates

\begin{abstract}
The research was aimed at an overview and analysis of the demonstration activities in the Czech Republic dealing with the transfer of innovations for agricultural practice. Several methods were used to compile the national inventory, in particular the questionnaire survey method. The Czech part of the research was based on 30 questionnaires conducted among both farmers and agricultural organizations engaged in demonstration activities. The questions were focused on a specialization in agriculture, type of the management, connections with networks and their size, types of demonstration activities according to the types of farms and non-productive activities. The most common topics and purposes for demonstration in the Czech Republic are recorded for the category arable land with combined crops. Highly linked to sustainability are activities such as conservation agriculture on arable land with combined crops, root crops and fodders mainly due to a reduction of soil erosion within crop production and animal health management and welfare for dairy within livestock production. The Ministry of Agriculture has prepared a subsidy program to help farmers in the form of illustrative practical demonstrations of comprehensive sustainable farming practices. The main added values for the end-users, if the generated knowledge is implemented, are to strengthen the knowledge transfer system in agriculture, focusing on practical demonstrations and presentation of sustainable farming systems and soil protection in practice. However, the demonstration activities support mostly technological development and some individual ecological measures whereas the sustainability of agriculture as the complex process unifying the crop and animal production is not in the foreground.
\end{abstract}

Keywords: knowledge exchange; innovation; demonstration activities; Czech agriculture

\section{Introduction}

Regional learning and innovation are key to promoting more resilient, robust and inclusive rural areas [1-3]. Similarly, Dwyer [4], Gamito and Madureira [5], Dicks et al. [6] or Lamine et al. [7] give innovations an important place in rural sustainability. How to assess the value of 'integrated farm management' as a concept for the promotion of sustainable agriculture is explained by Rose et al. [8]. However, to evaluate the financial and environmental aspects of sustainability of organic, integrated and conventional farming systems at farm level and on more detailed spatial scales is not easy, as Pacini et al. [9] point out, but possible. Läpple and Thorne [10] introduce the current focus of the Irish extension system on fostering the uptake of innovative technologies and practices in order to achieve an economically sustainable expansion of the dairy sector. Classical Schumpeter's theory [11] attaches to innovations a decisive importance in regional economic development. Strategies of advisory 
services were suggested e.g., by Abbasi et al. [12], Oliveira et al. [13], Toepfer et al. [14], Faure et al. [15] or Franzel et al. [16]. Toma et al. [17] highlight that the access to innovation is an important factor of agricultural development besides of pure economic factors.

Demonstration farms serve as a tool to overcome the gap between the research and practical experience of farmers $[18,19]$. They play an important role in dissemination of general knowledge but very often in an implementation of important state and public programs [20]. The demonstration of innovations brings not only the knowledge but also a motivation to farmers in order to create or improve the image of innovations [21-23]. This is important, especially in developing countries [24-26]. Many scholars are of the opinion that innovation networks are an optimum tool for the demonstration activities [27-29].

The project "Peer-to-Peer Learning: Accessing Innovation through Demonstration" (PLAID) is a project under Horizon 2020. It is ongoing during the period 2017-2019 and its aim is to assist European farmers to adopt innovations in agriculture, focused on a greater sustainability, through demonstration activities on commercial farms. The project is aimed at an inventory of demonstration activities in European countries, including on-line sources. A searchable geo-referenced database, which includes 769 farmers' and 406 organizations' entries throughout Europe was one of the deliverables. Some secondary targets were defined, namely the creation of a network among groups engaged in agriculture, promotion of best practices and a derivation of indicators for demonstration activities. The consortium includes 17 partners and additional subcontractors in different European regions.

Based on the PLAID project (https://www.plaid-h2020.eu/) consortium statement, it has long been established that farmers enthusiastically engage with knowledge transfer through demonstration activities, and that innovation and up-take of new farming technologies or practices result from interactive engagement with likeminded individuals or groups. Demonstration activities may also contribute to network building in agriculture communities, leading to longer term sustainability and economic development in rural areas. However, little has been documented on agriculture demonstration activities in European countries and the lack of an inventory or on-line resources have been identified.

The paper is aimed at an evaluation of a survey among the Czech demonstration farms focused on the demonstration processes and their impacts on farmers and agricultural companies. The results should manifest a probe into the issue of demonstration activities in the Czech agriculture.

\section{The Czech Agriculture and a Development of Innovations in the Knowledge Exchange}

The agricultural land in the Czech Republic covers currently 4.2 million ha, which is about $53.4 \%$ of the whole state area. The crucial part of this area 3 million ha (71\%) represents arable land. Permanent crops consist of permanent grassland (978 thousand ha), gardens and orchards (209 thousand ha), vineyards (19 thousand ha) and hop fields (10 thousand ha). Plant commodities include mainly cereals, oilseeds, pulses and fodder. The most common groups of crop cereals currently occupy about 1.6 million ha.

From the total harvest area of cereals in the Czech Republic in 2016, which was 1359 thousand ha, presents the largest share wheat (839.7 thousand ha, i.e., $61.8 \%$ of the total area) and barley (325.7 thousand ha, 24.0\%). The third most important cereal was corn for grain with an area of 86.4 thousand ha, accounting for $6.4 \%$ of the total area of cereals. Total livestock in the Czech Republic in 2016 according to the Czech Statistical Office represents: cattle: 1415 thousand pces; pigs: 1610 thousand pces.; sheeps: 218 thousand pces.; goats: 27 thousand pces.; poultry: 21,313 thousand pces. and horses: 32 thousand pces.

The main specifics of the Czech agriculture consist of the fact that the average farm size (ca $130 \mathrm{ha}$ ) is by far the largest in EU. The majority of the agricultural land is operated by leaseholders, not by owners, where owners are physical persons with small pieces of land whereas leaseholders are big agricultural enterprises the management of which is university educated as a rule. This fact impacts also on demonstration activities which are relatively on a high professional level. On the other side, 
farms with less than 500 ha and fewer than three employees have significantly worse information coverage [30-32].

The Czech agriculture has been productively oriented. The production has been mostly delivered to big customers. The specifics of the Czech farmers' knowledge consisted of the fact that they had little experience with marketing of agricultural products being focused on merge production. It limited their access and competitiveness to the agricultural market [33].

The adoption of non-productive activities is another factor which needs a dissemination of knowledge. Agri-tourism, organic agriculture and social agriculture have been developed only after the transformation and subsequent stabilization of the sector at the turn of the millennium. Environmental aspects in the case of the Czech intensive and concentrated agriculture have also an extreme significance. Relative diverse and changing system of European, national and regional subsidies asks for a permanent explanation as well.

The history of organized agricultural demonstrations goes back to the period of Austro-Hungarian Empire. An official education was provided by a relatively dense network of secondary agricultural schools which originated in 1880s. Agricultural universities were founded in Brno (1919) and Prague (1952). Agricultural associations and agricultural economic societies were engaged in the spread of agricultural knowledge. They contributed to speeding up the transition from triple to alternate farming, introducing new forage crops, technical crops, fruit growing development, flax farming, spreading machines, fertilizers, melioration, consultancy, agricultural literature, exhibitions. The later period (1924-1952) is connected with activities of the Czechoslovak Agricultural Academy (the third in Europe after Sweden and France). The socialist period was connected with the centralized control of the agriculture. On the other side, cooperatives management in agriculture became university educated, thus the strategy of knowledge-gaining was sophisticated and centrally directed. After 1989, separated Czech and Slovak Academies of Agricultural Sciences were created. They play their roles, besides of the research and education, in introducing new findings into practice and contribution to public awareness. Besides this, many private firms and associations aiming at demonstration activities on a commercial basis arose. The demonstrations are often directed to cope with the conditions of agricultural development within the Common Agricultural Policy.

Agrarian Chamber of the Czech Republic, regional and local agrarian chambers form another organizational basis. The following activities belong to their duties among others: they provide their members with advisory and consultancy services on issues related to business activity and organize professional education, advertising and widening the information about successful agricultural activities. The Agrarian Chamber includes non-governmental organizations like Agrarian Union of the Czech Republic, Bohemian-Moravian Union of Entrepreneurs in Agriculture and Agrarian Union of the Czech Republic. These associations provide advisory services and education in economic, business, legal and social spheres for their members. The Association of Private Agriculture, the Union of Ecological Farmers Pro-Bio or the Union of Rural Tourism and AgriTourism are other NGOs with demonstration activities.

\section{Materials and Methods}

\section{Mapping Demonstration Farms in the Czech Rural Space}

The research was made within an international project PLAID (Peer-to-peer learning) with the sub-title "Assessing innovation through demonstration within the EU HORIZON 2020 program" where Mendel University in Brno played the role of a sub-contractor. The project is managed by the James Hutton Institute in Aberdeen for the period 2017-2019.

\section{Data Collections}

There is data existing on the production volume and area of various crops, which can be retrieved from national statistics such as EUROSTAT (Europe) or FAOSTAT (global scale). However, there is not 
much data available on knowledge sharing in agriculture [33]. Farm Accountancy Data Networks $($ FADN) give good indications of the economic performance of farms in a given country, but they miss sufficient information on management. The best source of management data are large pilot farm surveys. The survey of Ryan et al. [34], which focused on sustainability of Irish farms, can serve as an example. If such surveys exist in the region being studied and the data is accessible, considerable time is still needed to analyze the data. In many regions, these surveys are not available and therefore, in general, other sources have to be used such as statistics, FADN, recommendations, documents from extension services, legislative norms, data from field experiments and expert knowledge in order to obtain representative data [35]. The process included literature reviews and a questionnaire survey.

Initially, available and active networks of agrarian entities were mapped. In addition, all other relevant networks and organizations in the Czech Republic related to the transfer of innovations and demonstrations in agriculture were identified, continuously contacted and classified by categories and topics. A questionnaire survey with closed questions was used as the main methodological tool for the investigation. There were two types of questionnaires developed: one for farmers, the second one for institutions dealing with demonstration activities. Both the questionnaires had a similar structure, only the choices of responses were adjusted. The questionnaires were standardized for participating countries and translated to individual national languages taking into account differences in languages and also in the realities in individual countries.

Ingram et al. [36] consider links between the demonstration objective, the functional characteristics and different forms and processes of learning for the most important in the process of the knowledge diffusion among farmers. Our questionnaire, as a method of the participatory research [37], was focused on three groups of problems. Inputs represented the first one. They included human, financial and technological conditions. A lack of sources manifests one of the most serious barriers in the diffusion of innovations [38]. Inclusiveness in geographical, social, and economic terms was the second category of questions. This category partly relates to the best practices [39]. The own demonstration process formed the third block of questions. It included methods, forms used and results obtained.

The questionnaire was elaborated by the consortium and translated to individual languages (Czech in our case). The target for the Czech part was to gain 30 respondents, including both farmers and organization active in agriculture under the condition that they develop some demonstration activities. The representativeness of the investigation was based on the attempt to cover different types of businesses, different types of activities and businesses in different natural conditions. The research was carried out during April of 2018. We tried to address subjects representing different types of activities in different regions. Only after gaining the agreement of the interviewees, were they approached for the survey process.

The survey contained the following group of questions: identification and contact information, specialization in agriculture, type of the management, connections with networks and their size, types of demonstration activities according to the types of farms. The activities in crop/plant growing were divided into following groups: biodiversity, consequences of the climate change, precision agriculture, protection of plants, ecological footprint, extensive agriculture, mechanization, new plants (e.g., energetic), new species, food production, quality improvements, management of fertility, new technologies, urban agriculture, water management. Similarly, activities concerning the animal breeding contained: welfare of animals, feeding, biodiversity, consequences of the climate change, breeding systems, machines, management of pastures, food production, quality improvement, minimization of risk in relation to the immunity against antibiotics, new technologies, and waste management. Among other activities, the following questions were asked related to: agritourism, alternative marketing, market models, EU Common Agricultural Policy and subsidies, business development, hunting and fishing, water protection, renewable energy, social agriculture. The questionnaire ended by an analysis and evaluation of demonstration activities: way of demonstrations, motivation, organization and an estimation of the quantity. 
After the first 73 questions, part B followed, which could be fulfilled voluntarily. It was directed to following problems: the financing of demonstration activities, frequency and length of the demonstrations, methods, demonstrating persons, and materials available for the participants, information channels, work with the feedback, an analysis of participants (listeners).

The questionnaires were fulfilled electronically, either on-line or with help of an interviewer with a tablet. About a one third (mostly individual farmers) of the respondents used the second option. Although the questionnaire contained 150 questions, its filling was quite rapid due to its form, which enabled skipping of individually irrelevant questions.

\section{Results and Discussion}

The analysis of the gender and age structure of respondents (Figure 1) shows that gender balance in demonstration is not equal. Men are more involved in all aspects (as initiators, organizers or participants). Men (over 90\%) participate at $74 \%$ of demonstration events. Generally, there is a balance between older and younger participants at both farmers and organizations. Due to the fact that we obtained more responses from farmers, there is a slightly higher involvement of older participants (age 40-55).

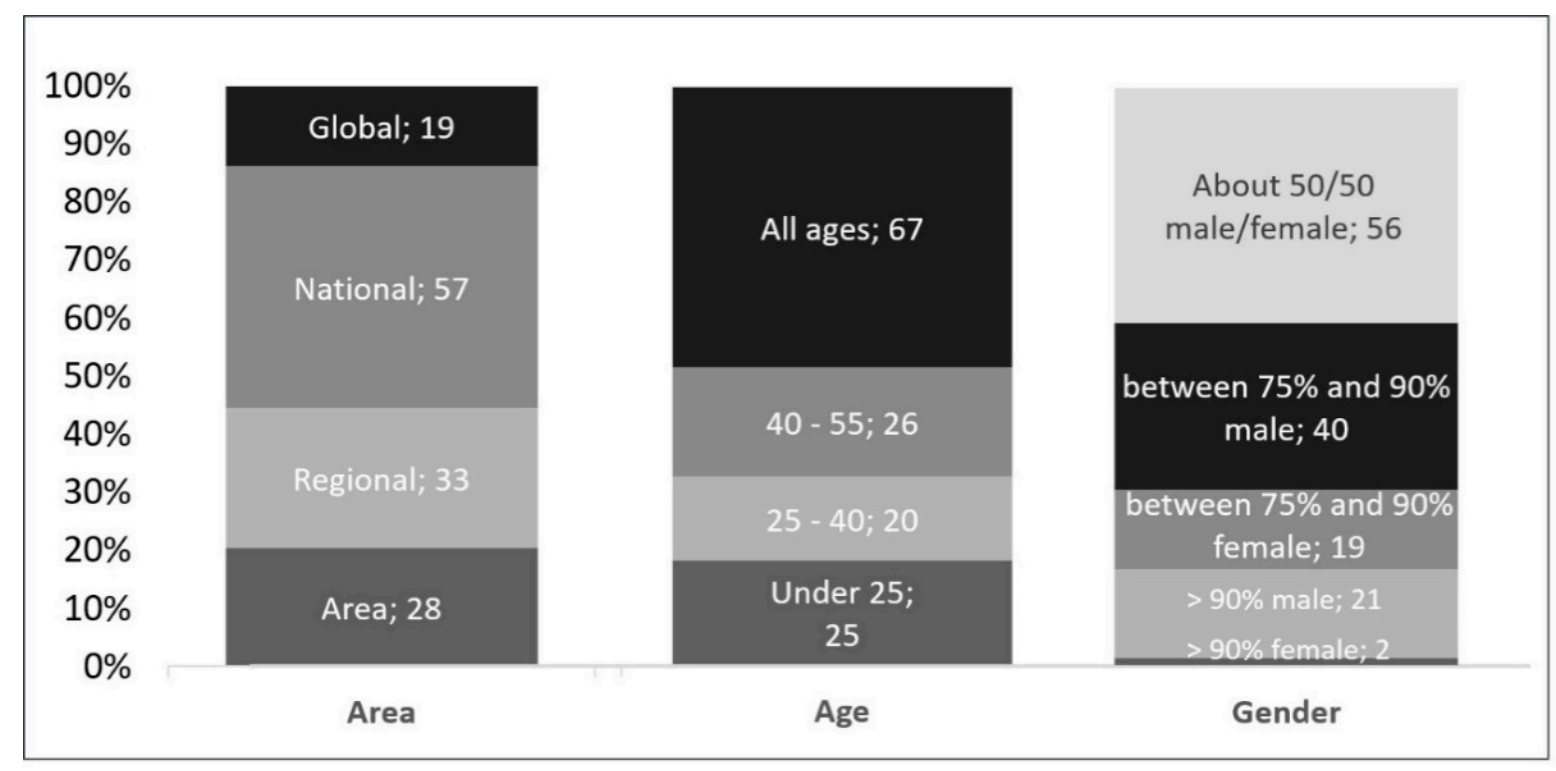

Figure 1. The structure of respondents of the questionnaire. Source: Own elaboration.

\subsection{Czech Demonstration Farms}

The most common topics and purposes for demonstration were recorded for the category on arable land with combined crops. Highly linked to sustainability were the following activities: conservation agriculture on arable land with combined crops (14/131-11 cereals, 9 corn, 6 pulse, 6 oils), root crops (9/131-7 potato, 3 sugar beet), fodders (9/131-6 lucerne, 5 grass, 5 clovers, 5 corn) mainly due to a reduction of soil erosion within crop production and animal health management and welfare for dairy (8/131-8 inside, 2 pasture) within livestock production (Figures 2 and 3).

Demonstration activities covering whole farm approaches prevailed for organizations (nine out of 14). Farmers focus on single technologies equally as to whole farm approaches. Providers of the demonstration are firstly individual farmers, then research institutions, followed by charitable organizations and NGOs (Figures 4 and 5). 


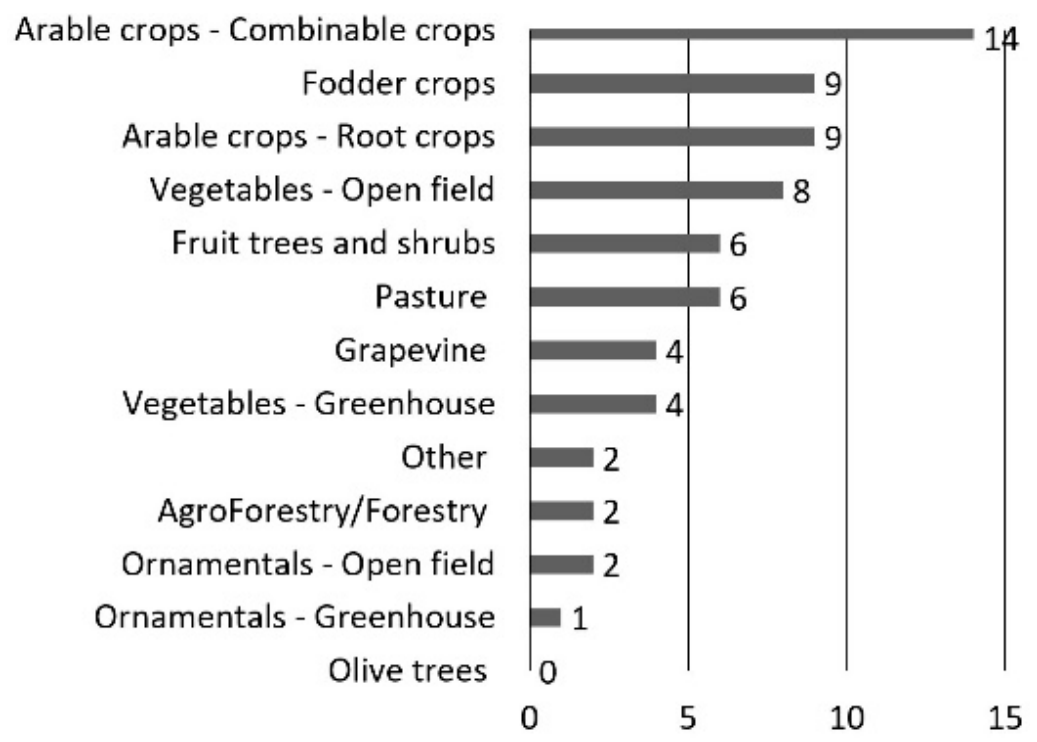

Figure 2. Types of crops used for demonstration activities. Source: Own elaboration.

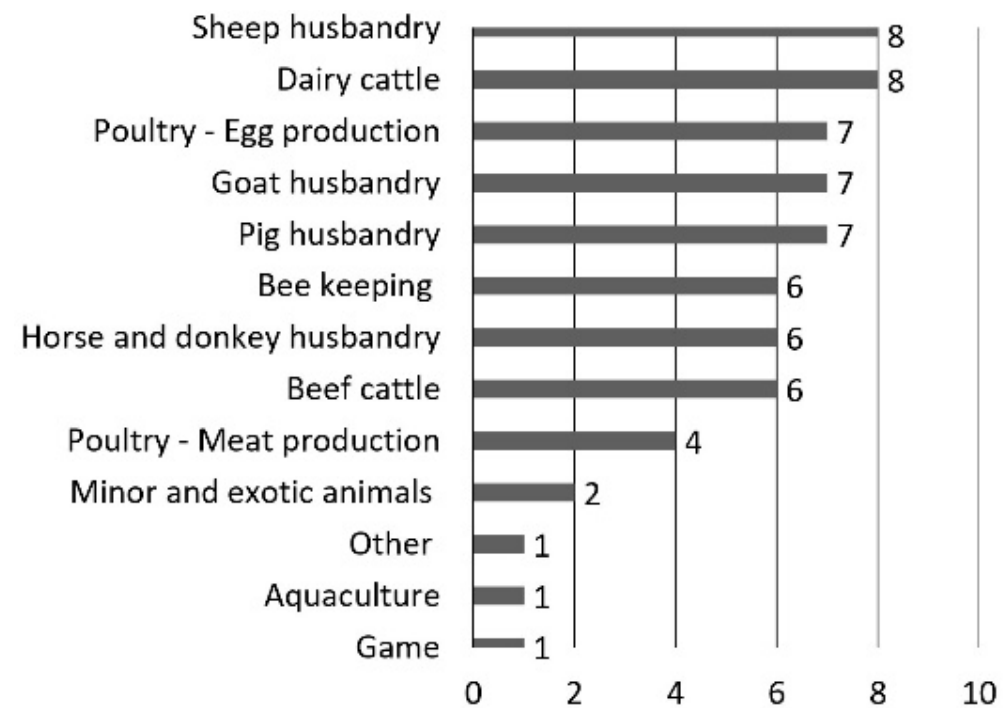

Figure 3. Types of animal production used for demonstration activities. Source: Own elaboration.

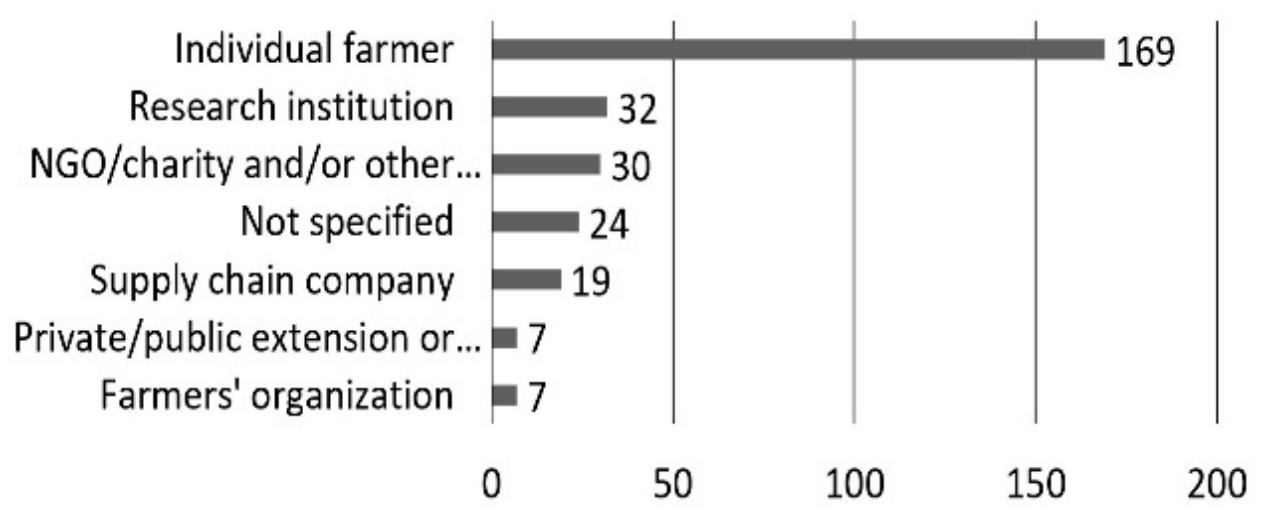

Figure 4. Providers of demonstration activities. Source: Own elaboration. 


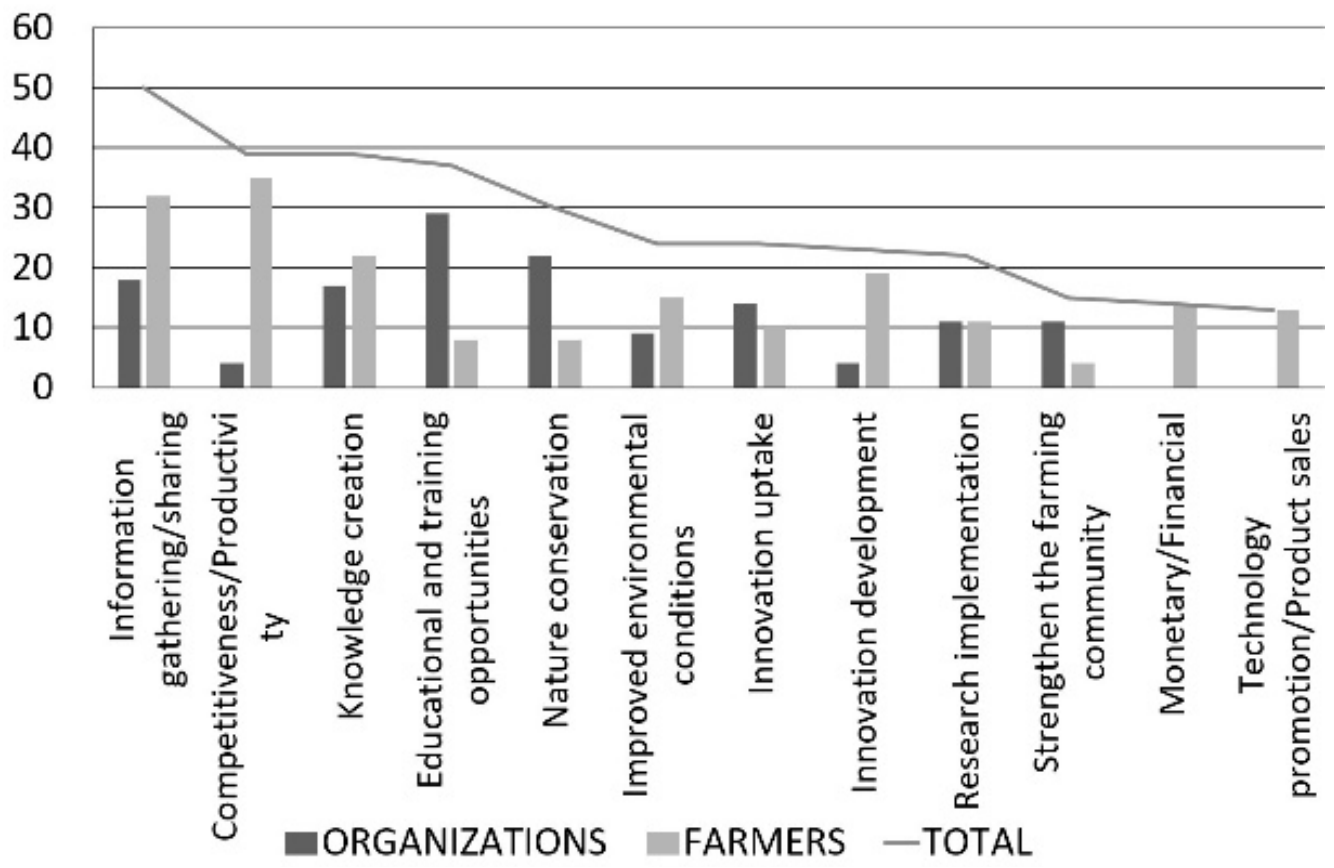

Figure 5. Purpose of demonstration activities. Source: Own elaboration.

Funders of demonstrations are mainly self-funded bodies (89 out of 300) followed by public bodies using e.g., regional, national and EU sources ( 84 out of 300$)$. Thirty respondents were identified regarding inventories for demonstration activities in the Czech Republic, where 17 were farmers and 13 belonged to organizations. This involves all 30 respondents who fulfilled part A of the survey. Only 3 organizations and 6 farmers did not continue with part B.

The most of recent Czech individual farmers started their own demonstration activities after "Velvet revolution" in 1989. There were mainly activities leading to the higher crop production, involving new technologies, machinery, pesticides and herbicides, new products of breading, etc. The intended audience was, other farmers led by farmers, research organizations presenting innovation in agro-technics and technologies (Figure 6).

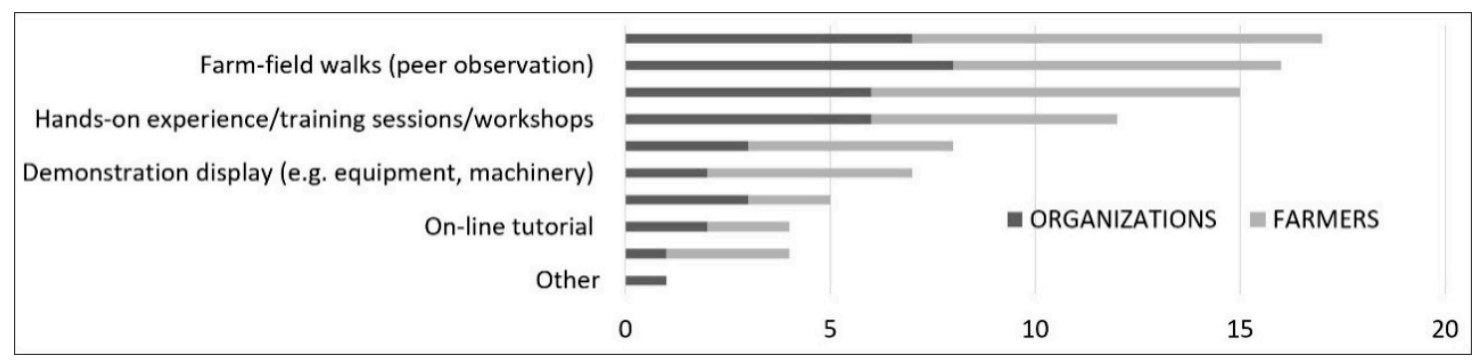

Figure 6. Type of demonstrations. Source: Own elaboration.

Providers of the demonstrations are firstly individual farmers (169 out of 264) then research institutions (32 out of 264) followed by charitable organizations and NGOs (30 out of 264). The main initiators, as well as organizers, are individual farmers.

Their activities cover:

- Information gathering and sharing,

- Productivity and competitiveness,

- Knowledge creation,

- Education and training opportunities. 
It is most common that farmers lead the demonstration activities (125 out of 300). In second place are researchers and students (118 out of 300). There is no particular topic; however, it always follows the main purpose/focus of the farm. It is not common that other figures in the food chain lead demonstrations. There are some big farms which cooperate with supply chain companies (e.g., Agro Jevišovice and Aleš Nováček), however it is rare. Demonstration activities differ depending on the figure, e.g., organizations are focusing on education and training opportunities (29 activities within organizations and eight activities at farmers) and demonstration activities related to a nature conservation (22 activities within organizations and eight activities at farmers).

There are no particular regions where there are more demonstrations than others, however types of demonstration activities (Figure 5) significantly represent local natural conditions, especially erosion problems and production region/area (sphere/cropping area) e.g., where production of particular crops, such as sugar beet, potato and corn, prevail.

Since 2016, the Czech Ministry of Agriculture started a formation of the method for a subsidy policy called "Demonstration Farm". The first seven individual farms were supported in 2017. The main topic for the year 2017 was "Soil protection".

The Ministry of Agriculture, in accordance with the "Strategy of the Ministry of Agriculture of the Czech Republic with a view to 2030", has prepared a subsidy program to help farmers in the form of illustrative practical demonstrations of comprehensive sustainable farming practices. In 2017, the program focuses on the area of soil care, with the emphasis on promoting the presentation of techniques and techniques to reduce water and wind erosion, excessive soil consolidation, practices contributing to water retention in the countryside, or presenting mitigation and adaptation measures in relation to climate change.

The Ministry's efforts to permanently promote the sustainable use of natural resources are an investment that can offer medium- and long-term economic benefits in the form of diversified, more innovative production and other services with positive environmental impacts, along with the creation of additional employment opportunities and an increase in the overall quality of life in the countryside.

The aim of the Demonstration Farm activities is to strengthen the knowledge transfer system in agriculture focusing on practical demonstrations and presentation of sustainable farming systems and soil protection in practice. They are supported by those who are new to their field of knowledge, have innovative and effective solutions in defined areas, whose crop rotation and technology meet the standards of good agricultural and environmental condition (DZES) and are in accordance with national legislation.

Grants are provided up to 1 million of CZK (ca. 40,000 of EUR). The Demonstration Farm, selected by the Demonstration Farm Selection Commission, subsequently submitted an application for subsidy from the national financial sources to the SAIF (State Agricultural Intervention Fund) by the deadline of 31 March 2017. The precise conditions were set out in the "Guidelines setting out the conditions for the provision of grants for 2017". The applicants chose one of the three plans for 2017, for which they worked out an action plan within the proposed project. The following intentions were supported in 2017:

- Presentation of integrated farming systems with an emphasis on soil protection,

- Technology of erosive crops cultivation in accordance with the standards of good agricultural and environmental condition of soils (as a part of the Cross Compliance),

- Organic matter in the soil and its influence on erosion, water management and its retention in the landscape.

The statute "Demonstration Farm" has received a total of seven agricultural entities that have met the basic requirements for granting this year's status, while meeting the requirements for innovation, experience with anti-erosion protection and the balance of crop rotation. One of them was Mendel University Agriculture Enterprise Žabčice (Figures 7 and 8). 


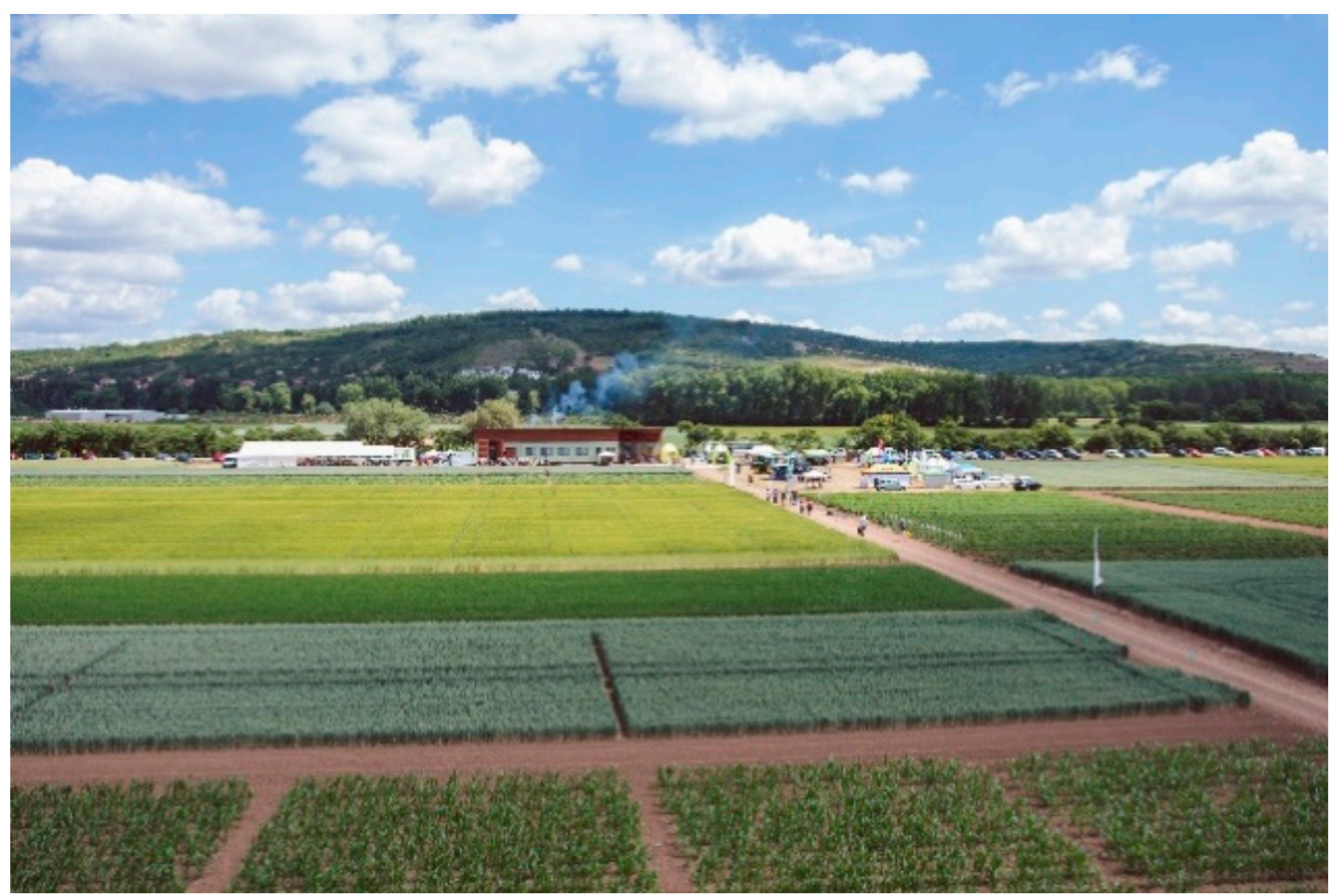

Figure 7. Demonstration farm of the Mendel University in Žabčice. Source: Archive of Faculty of AgriSciences at Mendel University in Brno.

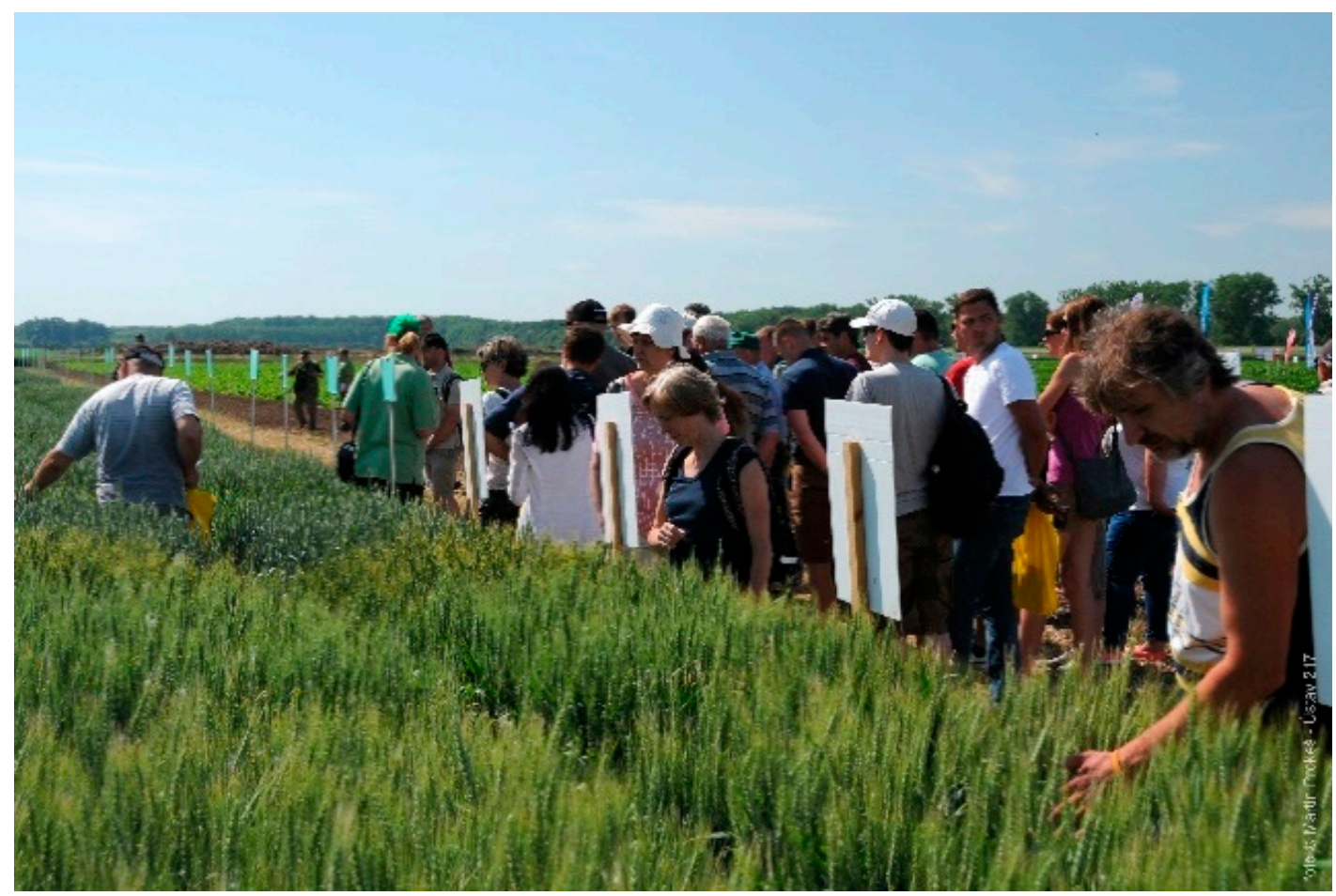

Figure 8. Field open exhibition at the demonstration farm in Žabčice. Source: Archive of Faculty of AgriSciences at Mendel University in Brno.

The applications were also filed with the SAIF. After discussing the formal pages of the individual applications to the SAIF, the Ministry of Agriculture decided on the definitive grant of the subsidy on the basis of the submitted documents. In 2018, the following aims of the support were added: 
- Integrated plant protection as a comprehensive arable land management system using agro-technical practices

- Organic farming as a comprehensive arable land management system based on the principles set out in Council Regulation (EC) No 834/2007 on organic production.

\subsection{Comparison with other European Countries}

Based on the inventory of on-farm demonstration across Europe, which was done by project partners and sub-contractors, there were identified trends in on-farm demonstration in the EU 28, Norway, Serbia and Switzerland. Findings from across Europe, focusing particularly on distinctions between three 'supra-regions', are presented below:

- Northern Europe: Belgium, Denmark, Finland, France, Germany, Ireland, the Netherlands, Norway, Sweden, Switzerland, and the UK,

- Central and Eastern Europe: Croatia, Czech Republic, Estonia, Hungary, Latvia, Lithuania, Poland, Romania, Serbia, Slovakia,

- Southern Europe: Austria, Bulgaria, Cyprus, Greece, Italy, Malta, Portugal, Slovenia, Spain.

Although over 1200 entries were in the inventory at the time of reporting, they are not seen as representative of all on-farm demonstrations in Europe [40].

The main topics of demonstrations in all of the countries, including the Czech Republic, are related to improving production (i.e., animal husbandry and crop-related issues). In general, there is more focus on technological innovation than on whole farm approaches. Technical aspects are also easier to demonstrate in a physical setting (e.g., outdoors or agricultural sheds). Within regions, the most common topics typically reflected the dominant commodities produced in that region (e.g., in an arable cropping region, arable cropping topics are most common).

Topics with an environmental focus also occur through Europe but are more common in Northern Europe. The economic utility of environmental actions is typically identified in the demonstration process to convince farmers of the feasibility of these actions. The social learning environment underpinning demonstration fosters development of social capital between farmers, advisors and researchers, but this is not usually the primary focus of demonstration activities.

Demonstrations are disproportionately likely to occur on organic farms. Demonstrations on organic farms are more likely to be based on whole farm systems (consistent with organic farming ethos), are more likely to be farmer-led, and are more oriented towards community values and the impact on the whole community than demonstrations on conventional farms.

Topics like farm succession are not usually the subject of demonstration, nor are topics relating to broader farm business management, and aspects of production where logistics prevent demonstration (e.g., risk of spreading livestock disease).

A range of different figures are involved in demonstration organization and implementation. Different types of organizer have different priority topics. Farmer-led demonstrations tend to focus on production systems, whereas organization or company-led demonstrations focus on specific techniques or inputs, and research-led demonstrations focus more on resilience and sustainability issues. However, all three types of organizer engage across all these topic areas.

Input suppliers (e.g., machinery dealers, fertilizer or seed providers) throughout the 20th and 21st centuries have utilized on-farm demonstration as a means of promoting their products. Food chain driven topics appear are the most recent form of demonstration (e.g., purchaser or collectors set up demonstration activities to advise farmers on how to produce the product characteristics they intend to buy, for example specific wheat varieties or new crops) as Sutherland et al. [41] show.

\section{Conclusions}

The research was aimed at an overview and analysis of the demonstration activities in the Czech Republic dealing with the transfer of innovations for agricultural practice. A questionnaire survey 
with closed questions was used as the main methodological tool for the investigation. A comparison of the situation with other countries was the main advantage, however, a limited possibility to include Czech specifics is the main shortage of such an approach. Nevertheless, the results represent a state of demonstration of agricultural knowledge at the present time. The results show that the knowledge exchange is still focused more on productive technologies, less on non-productive and multi-functional activities. The question is, to what extent does such an approach contribute to the sustainability of agriculture?

Moreover, in the Czech conditions, sustainability is often understood as mainly ecological or environmental sustainability which is in contradiction with social and, first of all, economic pillars. Highly linked to sustainability are activities such as conservation agriculture on arable land with combined crops, root crops and fodders mainly due to a reduction of soil erosion within crop production and animal health management and welfare for dairy within livestock production. Such a fact is strongly supported by the Czech government. The Ministry of Agriculture has prepared a subsidy program to help farmers in the form of illustrative practical demonstrations of comprehensive sustainable farming practices. The main added value to the end-user, if the generated knowledge is implemented, is to strengthen the knowledge transfer system in agriculture focusing on practical demonstrations and presentation of sustainable farming systems and soil protection in practice.

The results show that the majority of respondents are focused on crop production on arable land. This fact can be considered as one of the main limitations of a sustainable development in agriculture. Absence of the livestock production means a deep reduction of working force in the agriculture which has occurred in last 25 years. This could undermine the stability of the social pillar, but surplus labor was more or less absorbed by industry and service sectors. Moreover, the absence of the livestock production means substantial decrease of delivery of organic matters into the soil. This fact leads to a long-term reduction of soil quality and fertility, which can be seen as a major problem for the sustainability of agriculture. As Ryan et al. [30] show, the dairy farms indicate the highest level of economic and social sustainability in Irish conditions. Any whole-farm management without livestock production is hardly imaginable. Unfortunately, identified demonstration activities hardly react to these problems.

On the other side, a positive sign coming out of demonstration activities are connected with the organic agriculture in our investigation, which may improve the soil quality but also the quality of food in relation to the nutrient content and hence human health (Reeve et al. [42]). On the other side, the positive environmental impact of organic farming in comparison with the conventional one is at least questionable [42]. As it was stated, this approach does not relate to commercial farms. Moreover, according to the Ministry of Agriculture of the Czech Republic, there were 4023 of organic farms in Czech Republic in 2014. They operated 494,000 ha of agricultural land (11\%). However, of it, 402,000 ha were grasslands. As we found out, the most frequent dissemination activities were focused on the arable land, the mainstream of disseminations pass the organic farming.

Some principles of ecological intensification through knowledge dissemination have been suggested by Geertsema et al. [43]. It should be aimed at supporting biodiversity, ecological services and at complex social dynamics. An improvement of sustainability seems to be a social task that should be implemented and thus demonstrated mostly by public entities.

Author Contributions: Data curation, P.P.; Investigation, V.P.; Supervision, M.Š.; Validation, A.V.; Writing-original draft, M.Š.

Funding: The study was realized thanks to a sub-contract 9510/SV2170401 for the PLAID (Peer-to-Peer Learning: Accessing Innovation through Demonstration) project, funded by the European Commission Horizon 2020 programme under Grant agreement number: 727388.

Conflicts of Interest: The authors declare no conflict of interest. 


\section{References}

1. Wellbrock, W.; Roep, D.; Wiskerke, J. An integrated perspective on rural regional learning. Eur. Countrys. 2012, 4, 1-16. [CrossRef]

2. Surugiu, M.R.; Vasile, V.; Mazilescu, R.; Login, I.A.; Surugiu, C. Training for Heritage Promotion in Rural Areas. In Caring and Sharing: The Cultural Heritage Environment as an Agent for Change; Springer: Cham, Switzerland, 2019; pp. 251-259. [CrossRef]

3. DeRosa, M.; McElwee, G.; Smith, R. Farm diversification strategies in response to rural policy: A case from rural Italy. Land Use Policy 2019, 81, 291-301. [CrossRef]

4. Dwyer, J. New approaches to revitalize rural economies and communities-reflections of a policy analyst. Eur. Countrys. 2016, 8, 175-182. [CrossRef]

5. Gamito, T.M.; Madureira, L. Shedding light on rural innovation: Introducing and applying a comprehensive indicator system. Reg. Sci. Policy Pract. 2019, 1-27. [CrossRef]

6. Dicks, L.V.; Rose, D.C.; Ang, F.; Aston, S.; Birch, A.N.E.; Boatman, N.; Elliott, J. What agricultural practices are most likely to deliver "sustainable intensification" in the UK? Food Energy Security 2019, 8. [CrossRef]

7. Lamine, C.; Darnhofer, I.; Marsden, T.K. What enables just sustainability transitions in agrifood systems? An exploration of conceptual approaches using international comparative case studies. J. Rural Stud. 2019, 11. in press. [CrossRef]

8. Rose, D.C.; Sutherland, W.J.; Barnes, A.P.; Borthwick, F.; Ffoulkes, C.; Hall, C.; Dicks, L.V. Integrated farm management for sustainable agriculture: Lessons for knowledge exchange and policy. Land Use Policy 2019, 81, 834-842. [CrossRef]

9. Pacini, C.; Wossink, A.; Giesen, G.; Vazzana, C.; Huirne, R. Evaluation of sustainability of organic, integrated and conventional farming systems: A farm and field-scale analysis. Agric. Ecosyst. Environ. 2003, 95, $273-288$. [CrossRef]

10. Läpple, D.; Thorne, F. The Role of Innovation in Farm Economic Sustainability: Generalised Propensity Score Evidence from Irish Dairy Farms. J. Agric. Econ. 2019, 70, 178-197. [CrossRef]

11. Schumpeter, J.A. The Theory of Economic Development; Reprint; Routledge: London, UK; New York, NY, USA, 2017.

12. Abbasi, F.; Esparcia, J.; Saadi, H.A. From analysis to formulation of strategies for Farm Advisory Services (case study Valencia, Spain). An application through SWOT and QSPM matrix. Eur. Countrys. 2019, 11, 43-73. [CrossRef]

13. Oliveira, M.D.F.; Gomes da Silva, F.; Ferreira, S.; Teixeira, M.; Damásio, H.; Ferreira, A.D.; Gonçalves, J.M. Innovations in Sustainable Agriculture: Case Study of Lis Valley Irrigation District, Portugal. Sustainability 2019, 11, 331. [CrossRef]

14. Toepfer, S.; Kuhlmann, U.; Kansiime, M.; Onyango, D.O.; Davis, T.; Cameron, K.; Day, R. Communication, information sharing, and advisory services to raise awareness for fall armyworm detection and area-wide management by farmers. J. Plant Dis. Prot. 2019, 126, 103-106. [CrossRef]

15. Faure, G.; Knierim, A.; Koutsouris, A.; Ndah, H.T.; Audouin, S.; Zarokosta, E.; Heanue, K. How to Strengthen Innovation Support Services in Agriculture with Regard to Multi-Stakeholder Approaches. J. Innov. Econ. Manag. 2019, 1, 145-169. [CrossRef]

16. Franzel, S.; Kiptot, E.; Degrande, A. Farmer-To-Farmer Extension: A Low-Cost Approach for Promoting Climate-Smart Agriculture. In The Climate-Smart Agricultural Papers; Springer: Cham, Switzerland, 2019; pp. 277-288. [CrossRef]

17. Toma, L.; Barnes, A.P.; Sutherland, L.-A.; Thomson, S.; Burnett, F.; Matthews, K. Impact of information transfer on farmers' uptake of innovation crop technologies: A structural equation model applied to survey data. J. Technol. Transf. 2016, 43, 864-881. [CrossRef]

18. Yost, M.A.; Sudduth, K.A.; Walthall, C.L.; Kitchen, N.R. Public-private collaboration toward research, education and innovation opportunities in precision agriculture. Precis. Agric. 2019, 20, 4-18. [CrossRef]

19. Eitzinger, A.; Cock, J.; Atzmanstorfer, K.; Binder, C.R.; Läderach, P.; Bonilla-Findji, O.; Jarvis, A. GeoFarmer: A monitoring and feedback system for agricultural development projects. Comput. Electron. Agric. 2019, 158, 109-121. [CrossRef] 
20. Kudsk, P.; Jensen, J. Experiences with Implementation and Adoption of Integrated Pest Management in Denmark. In Integrated Pest Management; Peshin, R., Pimentel, D., Eds.; Springer: Dordrecht, The Netherlands, 2014; pp. 467-485. [CrossRef]

21. Reichardt, M.; Jürgens, C.; Klöble, U.; Hüber, J.; Moser, K. Dissemination of precision farming in Germany: Acceptance, adoption, obstacle, knowledge, transfer and training. Precis. Agric. 2019, 10, 525-545. [CrossRef]

22. Gardner, S.M.; Ramsden, S.J.; Hails, R.S. Agricultural Resilience; Cambridge University Press: Cambridge, UK, 2019.

23. Coutts, J.; Koutsouris, A.; Davis, K. Evaluation of rural advisory and extension services. J. Agric. Educ. Ext. 2019, 25, 99-101. [CrossRef]

24. Kumar, R. Crop technology demonstration: An effective communication approach for dissemination of wheat production technology. Agric. Sci. Dig. 2014, 34, 131-133. [CrossRef]

25. Shikuku, K.M. Information exchange links, knowledge exposure, and adoption of agricultural technologies in northern Uganda. World Dev. 2019, 115, 94-106. [CrossRef]

26. Anaafo, D. Between science and local knowledge: Improving the communication of climate change to rural agriculturists in the Bolgatanga Municipality, Ghana. Local Environ. 2019, 24, 201-215. [CrossRef]

27. Ingram, J. Framing niche-regime linkage as an adaptation: An analysis of learning and innovation networks for sustainable agriculture across Europe. J. Rural Stud. 2015, 40, 59-75. [CrossRef]

28. Rudnick, J.; Niles, M.; Lubell, M.; Cramer, L. A comparative analysis of governance and leadership in agricultural development policy networks. World Dev. 2019, 117, 112-126. [CrossRef]

29. Rzewnicki, P. Farmers' perceptions of experiment station research, demonstrations, and on-farm research in agronomy. J. Agron. Educ 1991, 20, 31-36.

30. Tyrychtr, J.; Ulman, M.; Vostrovský, V. Evaluation of the state of the Business Intelligence among small Czech farms. Agric. Econ. Czech. 2016, 61, 63-71. [CrossRef]

31. Kolackova, G.; Krejci, I.; Ticha, I. Dynamics of the small farmers' behavior-Scenario simulations. Agric. Econ. Czech. 2017, 63, 103-120. [CrossRef]

32. Tyrychtr, J.; Vostrovský, V. The current state of the issue of information needs and dispositions among small Czech farms. Agric. Econ. 2017, 63, 164-174. [CrossRef]

33. Syrovátková, M.; Hrabák, J.; Spilková, J. Farmers' markets' locavore challenge: The potential of local food production for newly emerged farmers' markets in Czech Republic. Renew. Agric. Food Syst. 2014, 30, 305-317. [CrossRef]

34. Ryan, M.; Hennesy, T.; Buckley, K.; Dillon, E.J.; Donnellan, T.; Hanrahan, K.; Moran, B. Developing farm-level sustainability indicators for Ireland using the Teagasc National Farm Survey. Irish J. Agric. Food Res. 2016, 55, 112-125. [CrossRef]

35. Nemecek, T.; Gaillard, G. Challenges in assessing the environmental impacts of crop production and horticulture: Chapter 6. In Environmental Assessment and Management in the Food Industry. Life Cycle Assessment and Related Approaches; Woodhead Publishing Limited: Oxford, UK, 2010; pp. 98-116. [CrossRef]

36. Ingram, J.; Mills, J.; Debruyne, L.; Cooleman, H.; Koutsouris, A.; Pappa, E.; Marchand, F. International Journal of Agricultural Extension. In Proceedings of the 13th European International Farming Systems Association Symposium (IFSA), Chania, Greece, 1-5 July 2018; pp. $29-42$.

37. Bellon, M.R. Participatory research methods for technology evaluations. A Manual for Scientists Working with Farmers; CIMMYT: Texcoco, Mexico, 2001.

38. Long, T.B.; Blok, V.; Coninx, I. Barriers to the adoption and diffusion of technological innovations for climate-smart agriculture in Europe: Evidence for the Netherlands, France, Switzerland and Italy. J. Clean. Product. 2016, 112, 9-21. [CrossRef]

39. Magette, W.L.; Weismiller, R.A.; Lessley, B.V.; Wood, J.D.; Miller, C.F. Demonstrating agricultural best management practice implementation and impact on a commercial farm. Appl. Eng. Agric. 1990, 6, 45-52. [CrossRef]

40. Sutherland, L.; Flanigan, S.; Brinks, H.; Kleshcheva, E.; Micheloni, C. On-Farm Demonstration in Europe. Findings from National Inventories; The James Hutton Institute: Aberdeen, Scotland, 2018.

41. Reeve, J.R.; Hoagland, L.A.; Villalba, J.J.; Carr, P.M.; Atucha, A.; Cambardella, C.; Davis, D.D.; Delate, K. Chapter six-Orhganic farming, soil health and food quality: Considering possible links. Adv. Agron. 2016, 137, 319-367. [CrossRef] 
42. Clark, M.; Tilman, D. Comparative analysis of environmental impcts of agricultural production systems, agricultural input efficiency, and food choice. Environ. Res. Lett. 2017, 12, 1-12. [CrossRef]

43. Geertsema, W.; Rossing, W.; Landis, D.; Bianchi, F.; van Rijn, P.; Scahminée, J.; Tscharntke, T.; van den Wolf, W. Actionable knowledge for ecological intensification of agriculture. Front. Ecol. Environ. 2016, 14, $209-216$. [CrossRef] 